\title{
Meningkatkan Prestasi Belajar Matematika Melalui Pembelajaran Student Team dengan Materi Peluang Siswa Kelas IX A MTsN 9 Ngawi Tahun Pelajaran 2017/2018
}

\author{
Mujiono \\ MTsN 9 Ngawi
}

\begin{abstract}
Abstrak
Penelitian ini bertujuan untuk (1) Mendeskripsikan model pembelajaran student team dalam meningkatan pretasi belajar matematika pada materi peluang pada siswa kelas XI A MTsN 9 Ngawi semester genap tahun pelajaran 2017/2018.; dan (2) Mendesripsikan upaya guru dalam meningkatkan prestasi belajar matematika pada materi peluang siswa kelas XI A MTs Negeri 9 Ngawi semester genap tahun pelajaran 2017/2018.Penelitian ini merupakan penelitian tindakan kelas (action research) karena penelitian dilakukan untuk memecahkan masalah pembelajaran di kelas. Subjek penelitian adalah siswa kelas XI-A MTsN 9 Ngawi. Prosedur penelitian dengan melakukan perencanaan, tindakan, observasi, dan refleksi.Hasil penelitian menunjukkan bahwa model pembelajaran tuntas memiliki dampak positif dalam meningkatkan prestasi belajar peserta didik. Hal ini dapat dilihat dari pemahaman peserta didik terhadap model pembelajaran student team dalam materi peluang, yang menunjukkan pada siklus I adalah $21.87 \%$, pada siklus II meningkat $81.25 \%$. Pada siklus ke II inilah ketuntasan belajar peserta didik telah tercapai. (1) Melalui model pembelajaran student team dapat meningkatkan prestasi belajar matematika pada materi pembelajaran peluang di kelas IX-A MTsN 9 Ngawi semester genap tahun pelajaran2017/2018. (2) Upaya dalam meningkatkan prestasi belajar matematika pada materi peluang melalui model pembelajaran student team di kelas XI-A MTsN 9 Ngawi semester genap tahun pelajaran 2017/2018, guru melaksanakan langkahlangkah model pembelajaran secara sistematis.
\end{abstract}

Kata kunci :Prestasi Belajar Matematika, Student Team, Peluang.

\section{PENDAHULUAN}

Pendidikan di era globalisasi saat ini menuntut adanya perkembangan di bidang ilmu pengetahuan. Era globalisasi menuntut dunia pendidikan untuk selalu mengubah konsep cara berpikirnya. Konsep berpikir lama dirasa sudah tidak sesuai lagi, dan mungkin tidak sesuai dengan masa-masa yang akan datang. Tantangan dan permasalahan selalu muncul seiring berjalannya waktu. Pendidikan harus berorientasi sesuai tantangan dan tuntutan zaman yang semakin berkembang. Untuk itulah, perubahan mesti dilakukan sesuai dengan perkembangan zaman. Dalam hal ini, tidak hanya guru yang berupaya mengembangkan ilmu pengetahuan, selain itu, penyelenggara pendidikan juga harus menghasilkan model baru dalam pengajaran dan pendidikan nasional. (Permana, 2015)Model pengajaran yang beragam dalam berbagai kondisi lingkungan berbeda untuk peserta didik dari lapisan masyarakat yang berbeda.

Belajar merupakan proses untuk memahami sesuatu yang baru dan menambah pengetahuan. Dilihat dari pengertian belajar tersebut, belajar tidak hanya memberikan ilmu pengetahuan kepada peserta didik, melainkan guru sebagai media belajar peserta didik selain buku pelajaran. Peran guru dalam 
mempersiapkan peserta didik untuk berpartisipasi aktif dalam kegiatan pembelajaran di sekolah, tidak sama dengan kondisi real di lapangan. Perlu adanya perubahan pandangan dalam mendekripsikan makna dari belajar peserta didik dan interaksi peserta didik dan guru. Lebih sepantasnya, kegiatan belajar mengajar juga harus mempertimbangkan peserta didik. Proses belajar tidak hanya dilakukan guru terhadap peserta didik, tetapi belajar bisa dari peserta didik dengan peserta didik. Proses belajar peserta didik dengan peserta didik, dimungkinkan lebih efektif daripada pengajaran yang dilakukan oleh guru kepada peserta didik. Model pengajaran rekan sebaya (peer teaching) selalu memberikan kesempatan peserta didik untuk bekerja sama dengan temannya dalam mengerjakan tugas, peran guru hanya sebagai fasilitator.

Seiring dengan perkembangan zaman, model pengajaran rekan sebaya akan mendorong kreativitas peserta didik dan lebih menyiapkan peserta didik ikut berpartisipasi di era globalisasi yang terus berubah dan berkembang pesat. Dibeberapa sekolah mungkin model pengajaran rekan sebaya atau lebih dikenal dengan diskusi kelompok sudah sering dipergunakan guru untuk memberikan tugas kepada peserta didik dalam berkelompok. Namun, dibeberapa sekolah model ini dirasa kurang efektif, karena banyak peserta didik yang tidak mengerjakan dan hanya peserta didik yang rajinlah yang mengerjakan. Sebenarnya banyak dampak negatif yang terjadi dengan model pembelajaran peer teaching. Dampak negarif bisa dihindari jika guru bersedia meluangkan waktu dan perhatian untuk mempersiapkan dan menyusun proyek kerja kelompok. Muhibbin (2005: 85) menyatakan ada lima unsur pokok tentang meningkatkan mutu pembelajaran, yakni saling ketergantungan positif, tanggung jawab individu, interaksi personal, keahlian bekerja sama, dan proses kelompok.

Pada keseluruhanprosespendidikandi sekolah, kegiatan belajar merupakan kegiatan yangpalingpokok.Iniberarti bahwaberhasil tidaknyapencapaiantujuan pendidikan banyak tergantung kepada bagaimana proses belajar yangdialami oleh siswa sebagai anak didik (Slameto, 2014). Setiaporangmempunyaipandanganyang berbedabedatentangbelajar.Perbedaanpendapat orang tentang arti belajar itu disebabkan oleh adanya kenyataan bahwa perbuatan belajar sendiri bermacam- macam. Banyak jenis perbuatan yang dapat dikatakan sebagai perbuatan belajar, misalnya mengumpulkan fakta- fakta,memahami rumus- rumus, menghitung dan mengerjakan soal-soal Matematikadan sebagainya(Yasin, 2016).

Dari latar belakang masalah tersebut, peneliti tertarik untuk melihat pengaruh pembelajaran terstruktur terhadap prestasi peserta didik dengan mengambil judul “ Meningkatkan Prestasi Belajar Matematika Melalui Model Pembelajaran Student Team dengan Materi Peluang Siswa Kelas XI A MTsN 9 Ngawi Tahun Pelajaran 2017/2018"

\section{METODE PENELITIAN}

Metode Penelitian yang digunakan yaitu penelitian tindakan kelas (PTK) (classroom action research) (Martin, 2008) PTK ini menggunakan model guru sebagai peneliti (teacher as researcher) (Ryan et al., 2017). Model ini relevan bagi guru dan memiliki keunggulan, sebab efektif dapat memperbaiki kualitas pembelajaran yang dilakukannya. Menurut Mukhlis (2000: 5) penelitian tindakan kelas adalah sesuatu bentuk kajian yang sifatnya sistematis reflektif oleh pelaku tindakan untuk 
memperbaiki kondisi pembelajaran yang dilakukan. Penelitian ini menggunakan guru sebagai peneliti, yang mana guru sangat berperan dalam proses penelitian tindakan kelas.Mulyasa (2006: 97) mengelompokkan penelitian tindakan menjadi empat macam, yaitu: 1) guru sebagai peneliti, 2) penelitian tindakan kolaboratif, 3) simultan terintegratif, 4) administrasi sosial eksperimental.

Tempat penelitian adalah tempat yang digunakan dalam melakukan penelitian untuk memperoleh data yang diinginkan. Penelitian ini bertempat di MTsN 9 Ngawi Tahun Pelajaran 2017/2018. Subjek peneitian pada penelitian ini merupakan siswa kelas XI-A MTsN 9 Ngawi tahun pelajaran 2017/2018. Dan waktu berlangsungnya penelitian atau saat penelitian ini dilangsungkan pada bulan Januari sampai Februai tahun pelajaran 2017/2018.

\section{HASIL DAN PEMBAHASAN \\ Siklus I}

Pada tahap ini peneliti mempersiapkan perangkat pembelajaran yang terdiri dari rencana pembelajaran dan alat pengajaran yang mendukung. Selain itu, juga dipersiapkan lembar tugas untuk menganalisa pemahaman terkait dengan materi yang diajarkan. Hasil menunjukkan bahwa dengan menerapkan pembelajaran tuntas diperoleh nilai rata-rata prestasi belajar peserta didik adalah 58.46 dan ketuntasan belajar mencapai $21.87 \%$ peserta didik sudah tuntas belajar. Hal tersebut menunjukkan bahwa pada siklus I secara klasikal peserta didik belum tuntas belajar. Hal ini karena peserta didik yang mendapat nilai $<70$ hanya sebesar $21.87 \%$ lebih kecil dari presentase ketuntasan yang dikehendaki,yaitu sebesar $80 \%$. Penyebabnya adalah peserta didik masih belum memahami apa yang dijelaskan oleh guru dengan menerapkan model pembelajaran tuntas.

\section{Siklus II}

Hasil siklus II menunjukkan bahwa dengan menerapkan pembelajaran tuntas diperoleh nilai rata-rata prestasi belajar peserta didik adalah 76.31 dan ketuntasan belajar mencapai $81.25 \%$ peserta didik sudah tuntas belajar. Hal tersebut menunjukkan bahwa pada siklus II secara klasikal peserta didik sudah tuntas belajar. Hal ini karena peserta didik yang tuntas belajar mencapai 26 peserta didik. Penyebabnya adalah peserta didik sudah memahami konsep yang dijelaskan oleh guru dengan menerapkan model pembelajaran tuntas.

\section{SIMPULAN}

Berdasar pada hasil penelitian diperoleh bahwa ketuntasan belajar siswa secara klasikal mengalami peningkatan dari siklus I dengan presentase ketuntasan $21.87 \%$, sedangkan pada siklus II sebesar $81.25 \%$. Dengan demikian, siklus II ketuntasan belajar peserta didik secara klasikal telah dinyatakan tuntas. Maka, sebagai hasil akhir penelitian ini dapat disimpulkan bahwa melalui model pembelajaran student team dapat meningkatkan prestasi belajar matematika pada materi pembelajaran peluang di kelas IX-A MTsN 9 Ngawi semester genap tahun pelajaran2017/2018.Upaya dalam meningkatkan prestasi belajar matematika pada materi peluang melalui model pembelajaran student team di kelas XI-A MTsN 9 Ngawi semester genap tahun pelajaran 2017/2018, guru melaksanakan langkah-langkah model pembelajaran secara sistematis. 


\section{SARAN}

Berdasar pada hasil akhir penelitian, dikemukakan saran antara lain. Dalam melaksanakan model pembelajaran student team memerlukan persiapan yang cukup matang sehingga guru mampu menentukan topik yang benar-benar bisa diterapkan, sehingga akan memperoleh hasil yang maksimal.Dalam rangka meningkatkan prestasi belajar peserta didik, guru hendaknya lebih sering melatih peserta didik dengan berbagai metode pengajaran yang sesuai.Perlu adanya penelitian berikutnya, karena hasil penelitian ini hanya dilakukan di MTsN 9 Ngawi semester genap tahun pelajaran 2017/2018.Untuk penelitian yang sejenis hendaknya dilakukan perbaikanperbaikan agar diperoleh hasil yang lebih baik.

\section{DAFTAR PUSTAKA}

Martin, L. A. (2008). Elementary and Secondary Teacher Education Students' Perspectives on Citizenship. Action in Teacher Education, 30(3), 54-63. https://doi.org/10.1080/01626620.2008. 10463502

Muhibbin. 2005. Psikologi Pendidikan dengan Pendekatan Baru. Bandung: Remaja Rosda Karya.

Mukhlis. 2000. Penelitian Tindakan Kelas. Makalah Panitian Pelatihan Penulisan Karya Ilmiah untuk Guru-guru seKabupaten Tuban.
Mulyasa. 2006. Kurikulum Tingkat Satuan Pendidikan. Jakarta: Depdiknas.

Permana, E. P. (2015). Penerapan Metode Problem Solving Dengan Media Gambar Seri Untuk Meningkatkan Hasil Belajar IPS Kelas IV Sekolah Dasar. Jurnal Pendidikan Dasar Nusantara, 1(1), 116.https://doi.org/10.29407/jpdn.v1i1.1 52

Ryan, M., Taylor, M., Barone, A., Della Pesca, L., Durgana, S., Ostrowski, K., ... Pikaard, K. (2017). Teacher as Researcher, Teacher as Scholar, and Teacher as Leader. The New Educator, 13(2), 102-116. https://doi.org/10.1080/1547688X.2016 .1144120

Slameto. (2014). Primary School e-Learning Development as a Social Study Learning Model in the 5th Grade Primary School. International Journal of E-Education, E-Business, EManagement and E-Learning, 4(5), 351-360. https://doi.org/10.7763/ijeeee.2014.v4. 350

Yasin, M. (2016). Penerapan Tutor Sebaya Untuk Meningkatkan Prestasi Belajardan Ketuntasan Belajar Matematika pada Kompetensi Dasar Trigonometri Siswa Kelas XI IPA-1 SMA Negeri 1 Kauman. PINUS: Jurnal Penelitian Inovasi Pembelajaran, 2(1), 28-32. https://doi.org/doi.org/10.29407/pn.v2i 1.267 